\title{
The Israeli Intelligence Community
}

\author{
Antonella Colonna Vilasi \\ Centro Studi University, Rome, Italy \\ Email:mavil@tiscali.it
}

How to cite this paper: Colonna Vilasi, A. (2018). The Israeli Intelligence Community. Sociology Mind, 8, 114-122.

https://doi.org/10.4236/sm.2018.82009

Received: February 26, 2018

Accepted: March 27, 2018

Published: March 30, 2018

Copyright (c) 2018 by author and Scientific Research Publishing Inc. This work is licensed under the Creative Commons Attribution-NonCommercial International License (CC BY-NC 4.0). http://creativecommons.org/licenses/by-nc/4.0/

\begin{abstract}
The Israeli Intelligence Community is made up of Aman (military intelligence), Mossad (overseas intelligence) and Shin Bet (internal security). This analytical, theory-building article examines the Israeli Intelligence, the jurisdiction, organization and Departments from a different perspective, evaluating the culturally transmitted factors that influence political and military elites, security communities, and decision-makers.
\end{abstract}

\section{Keywords}

Intelligence, Military Intelligence, Security, Israeli Intelligence, Society, Politics

\section{Introduction}

The notions of security and stability are central to our contemporary society. Social and State security are a major pillar if not a prerequisite of a democratic system. The ability or inability to provide security is central to democratic Nations.

In the near future the Intelligence agencies and governments will increasingly depend on those warning mechanisms which can promptly respond to an even more and complicated task, the prevention of security.

The following article is about the Israeli Intelligence Community, namely Aman (military Intelligence), Mossad (overseas Intelligence) and Shin Bet (internal security).

With reference to this research, the first question posed is: how was Intelligence capable of addressing the challenges posed by a new born country?

Second question: what are the capabilities, know-how and analysis tools that

${ }^{\star}$ Pioneer in Intelligence Studies in Italy, the author's research interests focused on Intelligence, the relation with the Political Science and the Intelligence Cycle. With more than 70 books published on the topics; among them: The Intelligence Cycle, The History of M16, The History of the CIA, The History of the Italian Secret Services, The History of the Entity, The History of Mossad, and The History of the STASI. 
Intelligence needs in such a new and complex reality (a Nation that was born after the Second World war, the antisemitism and the Shoah) as to require a new approach?

This study uses a three-step methodological approach: data collection, coding and analysis, using qualitative techniques.

In particular using a three-stage process includes:

- a discovery phase of data collection;

- a coding phase using some of the analytical techniques and proposed methodologies as filters;

- an analysis phase using argumentation analysis and Intelligence analysis.

The article offers a number of original contributions to the scientific literature.

First, it re-examines the sources and the theory-building and proposes alternatives to the referable scientific literature accepted and proposed by the majority of scholars.

Secondly, it strengthens the holistic interrelations in terms of consistency between disciplines such as Intelligence studies, history, sociology, political geography, and political science.

The article's mixed methods approach advances a research agenda that addresses potential analytic and cognitive biases that can affect the "at a distance" examination of the Israeli Intelligence Community. A new understanding will emerge on how we can contribute to analysing the previous and future core of the Israeli Intelligence Community. Thirdly, the proposed mixed methods approach generate an agenda for possible future studies and researchs. The documents used refer to Open Source documents, archives, publications, and reliable secondary sources.

The article relies on selected primary sources where possible, and a mixed methods, evalutative approach to secondary sources. The crucial gaps in some of the comparative sources are crossed over with new available data.

The limitation of this research is due to the fact that it should be treated with an entire volume, and not only with a brief article.

\section{Literature Review}

Academic studies, apart from the bibliography proposed in the article, refer mainly to the international studies of the sector. It is impossible in this brief article to mention the vast literature of the field.

Not to mention Colonna Vilasi (2014). The History of Mossad, we can trace a long stream of Intelligence studies dealing with the Israeli Intelligence Community and we can state: Andrew (2009). The Defence of the Realm, Desmaretz (1999). Le grand livre de l'espionnage, Morris (2000). 1948 and after. Israel and the Palestinians, Jeffery (2010). MI6: The History of the Secret Intelligence Service 1909-1949, Lituinoff (2002). La lunga strada per Gerusalemme, Morris \& Black ( 2013). Mossad-Le guerre segrete di Israele, Ostrovsky \& Hoy (1996). 
Attraverso l'inganno.

As far as the Information collection here studied is concerned, it derived from covert sources (from the Defense or other Intelligence agencies), or from Open Source documents like: archives, publications, radio, TV, newspapers, scientific dissertations, and secondary sources as well.

The main argument is that a structured and composed Intelligence organization is of utmost relevance in a country situated in a critical geopolitical area.

This article can thus be a contribution to the gap in the literature of the field, and the relevance is due to the fact that the Israeli Intelligence Community is going to be in the limelight even if still covered with a thick layer of secrecy.

\section{Jurisdiction, Organization and Departments}

David Ben Gurion created the Israeli Intelligence in 1951, in order to defend the new born Nation.

In addition to Mossad, the Intelligence Community includes Agaf Modin (or Aman), Shabak (or Shin Bet), and Lakam (dismantled in 1987).

Mossad has always been the symbol of security for all the people living in the State of Israel and soon became the emblem of efficiency and invincibility, as if it represented the guarantee for the survival of a statehood surrounded by enemies.

The "Institute" (Mossad) created a protective barrier around the Jewish State mainly through actions characterized by detached calculations and impeccable efficiency.

However, as a result of some failures few years ago it has been claimed to be not much reliable.

Anyway, in the present day Mossad got back to the previous standards of organisational and operative excellence, characterizing the "Institute" since the creation.

The political interference in the Israeli Intelligence Community is an everlasting topics in the history of the Israeli Intelligence, creating pressure through demands and a strict control on the Intelligence activities, but also avoiding to take charge when the operations weren't successful.

For this reason the Lavon case is emblematic, instigating a recurring question (it is an event that kept on having consequences for almost two decades): "Who gave the word?" this is a question that can be repeated also for the 1986 scandal, caused by the killing of some Arabian prisoners by Shin Bet and the recruitment of the Jewish-American spy Jonathan Pollard, whose capture and identification caused considerable hitches in the relationship between the US Intelligence and Israel.

Pollard was a link between some CIA agents and Israel and he purloined very important files-considered top secret-from the American Government to the agents of Tel Aviv.

Once unmasked the spy was given a life sentence; the Pollard affair had serious consequences and the bilateral relationship between the two States was se- 
riously cracked.

In 1948, indeed, Israel burst on the worldwide scene fighting among the ruins of the British Mandate (Jeffery, 2010), making use of the lack of organization and coordination between the Palestine people and their supporters in the Middle East.

The Intelligence activity has two goals: to forecast and prevent menaces from the enemy and the transmission of information and evaluations based on careful studies that can be the basis for the National policy (Colonna Vilasi, 2014).

When these two goals cannot be reached, the consequences can be catastrophic: an example is the war of October 1973, during which the responsibility of the initial failure was given almost totally to the military information service; another one is the project that led up to the invasion of Lebanon in 1982, that had great perspectives but it failed as soon as it was put into action.

After the Sadat historic visit to Jerusalem in 1977 and the following peace treaty with Egypt, the peace with Jordan and the loosening of the PLO armed conflict after the first Lebanon war did not mean that the Israeli Intelligence ended its mission.

From the very beginning, in the 30's, under the British Mandate (Andrew, 2009) and founded by a group of volunteers who fought for the Haganah militia in Palestine (reporting information), the Israeli Intelligence has proved a great evolution, becoming a real independent organism.

Today, indeed, the military information section (Aman) of the IDF (Israeli Defence Forces), Mossad and Shin Bet involve lots of people and spend hundreds of millions of dollars every year to defend Israel from the frequent assaults of the enemies, in order to find out their secrets and to infiltrate in their ranks.

In the Middle Eastern conflict the stake is too high and the Intelligence has a very important role in the historical, political and international context (Morris \& Black, 2013).

\section{Mossad}

Mossad (Ha-Mossad le-Mod'in ule-Tafkidim Meyuchadim) is certainly the flagship of the Israeli Intelligence; it means: the "Central Institute for the Intelligence and Special Missions", it works abroad and the headquarters are in Tel Aviv.

On March 2, 1951 Ben Gurion created the "Institution for the coordination", called "Ha MossadLe Teum" and on April 1, 1951 the operations started under the command of the founder and first director Reuven Shiloah.

In 1963, the institute changed name in the current one, in other words "Institute for Intelligence and Special Operations".

In July 1949 Shiloah sent a letter to Ben Gurion in which he was asking for the creation of a central Institution for safety and information, set under the Prime Minister's control; this was the first step for the creation of the Israeli Intelligence (Morris \& Black, 2004). 
At the beginning the "Institute" had to ride over some difficulties; at the end of the 50's there were some problems due to the political division and with the IDF.

Finally, the concrete need to unify every operation under the control of Mossad solved the problem, integrating the Intelligence in just one organization.

Mossad is divided in different Departments, which perform different functions; the Department for Special Operations has a role of particular importance.

Over the years the "Institute" reshaped the Departments, reducing the number of agents from more than two thousands to the current one thousand and two hundreds, divided as follows:

- Collection Department: it represents the biggest and most articulated one, directly responsible for the abroad operations. It includes a series of operative sections in different part of the earth and each of them can count on a head official on the site who, in turn, has at his disposal some agents;

- Political Action Department: is responsible for working with allied foreign Intelligence agencies, and those Nations that don't have diplomatic relations with Israel;

- LAP Department (Lohamah Psichlogit): it overlooks the psychological war and propaganda;

- Special Operation Division: known also as Metsada and then renamed Komemiute, it has mainly an operative role; it represents the military wing of Mossad and is in charge of sabotage operations and of the elimination of selected targets. Kidon-the famous elite section-belongs to this Department and it includes the "superkiller" agent. It has a lot of freedom in actions and it proved the efficiency to guarantee the National Security.

Once ended the cold war, however, the emergency seemed to be arrived to an end and the Mossad agents had to check and reshape their action strategies; in this way the recruitment of intellectuals and scholars was put first rather than action men highly qualified.

In the international field a collaboration with the Egyptian and Palestinian Intelligence was implemented to find a new solution for the Middle East peace process (Rodison, 1986).

The most delicate phase consists in the recruitment and training of agents; a wrong evaluation can have catastrophic consequences and there is no room for errors.

For this reason, according to the ex-agent Victor Ostrovsky (Ostrovsky \& Hoy, 1996), after the potential agent is identified, he is subjected to through the mill even for months.

Once the recruitment phase is over, then starts the real training (that lasts two years) inside the Midrasha, the Mossad's school.

The exceptional hardness of the training ensures that only a little part of the selected men end their path; the proportion is about 15 over 500 .

Each aspiring agent, or katsa, must count on a trusty informers' web of his own and to reach this aim, according to Yehuda Gil-a real expert in recruit- 
ment-the best way is money (that cannot be forgotten), unlike sex.

The most important non-operative Department is the Research one (Lakam), which has the task of recollecting and analyzing all the gathered information, drafting weekly and monthly reports.

This Department is divided into fifteen more divisions, one for each geographical area: USA, Canada and Eastern Europe, Latin America, Russia and the ex USSR countries, China, Africa, Maghreb (Morocco, Algeria, Tunisia), Libya, Iraq, Jordan, Syria, Saudi Arabia, Emirates and Iran. In addition, it has also a Nuclear division that is specialized in the atomic issue, supervising other countries' activities.

\section{Shabak (Shin Bet)}

On June 30, 1948 the Israel Security Agency-Shin Bet-was created and until 1950 it was part of the IDF, which provided support, military ranks and salaries.

Most of the agents assigned had contributed to the organization of the self-defence and the Jewish immigration from the freed Europe.

Isser Harel, memorable head of the Shin Bet, had always restated the need of a security Agency composed by civil agents, in order to guarantee the management of the budget, offices and staff without submitting them to the military system.

At the beginning, it was affiliated to the Ministry of Defence but after only a year from the foundation it became an independent organization accountable of its actions only to the Prime Minister; the obligation is still valid and it allowed the Shin Bet to expand the freedom of action.

At the beginning the Agency was hidden and became totally operative only from 1953, when Amos Manor assumed the command; he made his mark and reputation as head of the soviet bloc division for the counter-intelligence.

The Shin Bet supervised the incoming of immigrants from the iron curtain bounder and from the Jewish communities of the Eastern Europe; the immigrants gave important information that Israel gave into the hands of the other countries' Intelligence, especially the CIA.

In 1948 the Arabic population of Israel counted on 156.000 people, while during the 50's counted on 200.000 people; this number is useful to understand the importance of an Intelligence Agency that was able to keep under control the possible inner subversive revolts, especially for religious minority groups inside the country (Lituinoff, 2002).

The menace of the Arabic community in Israel became evident in 1964, when the Ministry of Defence outlawed the "Arabic Front", better known as Al-Ard (the earth), a decision that the Shin Bet itself encouraged and controlled.

The Shabak was operative mainly in the Jewish settlements and in the territories managed by the Palestinians; for this reason it has always been considered an organization with an impeccable efficiency but on November 15, 1995 the reputation began to crack when Ygal Amir, a right-wing radical, killed the Prime 


\section{Minister Yitzhak Rabin.}

It is composed of three operative Departments:

- Arabic Affairs Department: it is the most important, and it is specialized in monitoring, and keeping under control the potential subversive activities and those suspected of Arabic radicalism, such as the members of Hamas. This division was reorganised and strengthened during the Intifada, when special troops known as HENZA operated in order to monitor the insurrection areas.

- Non-Arabic Affairs Department: it is specialized in obstructing the infiltration of other countries' Intelligence agencies in Israel; in the past there was a special attention towards the East European Countries immediately before the fall of the Berlin Wall.

- Security Department: it is specialized in protecting the Israeli activities and companies from the terrorist attacks.

A long period was characterized by the fight against the violent intifada that had blown up inside the Country.

In 1989, during the second anniversary of the Palestinian revolt, the Shin Bet Departments definitely improved their organization and, while the Palestinians in the West Bank and in the Gaza Strip conveyed their efforts, there was a change in the pullback.

It consisted in demonstrations throwing stones, and afterwards in rapid attacks of little groups of masked activists, organized in a cellular structure; the Shin Bet managed to tackle proficiently this change, despite the bloody repression of lots of informers.

The Division strengthened the collaboration with the IDF, appointing linkage officials in order to take the best advantage from the illegal immigrants, as happened in Gaza at the beginning of the 70's.

Moreover, some Shin Bet agents-working side-by-side with the army-tracked down and killed the members of two little armed groups affiliated to Al-Fatah, the Black Panthers and the Red Eagles (both linked with the PFLP that operated in Nablus).

Some months earlier, the Shin Bet had captured hundreds of people and demolished completely the military area of Hamas in the Gaza Strip.

Prisoners kept on being a fundamental source of information: at the end of 1989, the Palestinians imprisoned were about 10.000. Furthermore, the Shin Bet stopped the Palestinian opposition in the West Bank and in the Gaza Strip.

From this moment on, the rebellion started declining and, after a failed landing in the Israeli coast organized by the Popular Front for the Liberation of Palestine (PFLP), the United States decided to stop any communication with the PLO.

When in 1990 the Iraqis invaded Kuwait, the Palestinians decided to side with Saddam Hussein. Such position was a tremendous mistake as damaged the political and economical status-quo. 
It stopped the communication with the Israeli left wing and the financial help from the Arabic countries.

Due to these facts, the Shin Bet improved the domestic security actions in order to foster the negotiations on the West Bank and of the Gaza Strip.

\section{Agaf Modin or Aman (The IDF Intelligence)}

More than seven thousands people work in the Aman; it coordinates the information received from different structures, in other words the ELINT (Electronic Intelligence) and the COMINT (Communication Intelligence), later passed and analyzed by the Sayet Maktal, the anti-terrorism Unit.

The military Intelligence, moreover, must inform the Prime Minister and the Cabinet about all the potential menaces from the terrorists and the enemy countries with a yearly report consisting in the information reached.

Following the Israeli spy satellites put into orbit, the Israeli Intelligence could finally emancipate from the American support.

\section{Conclusions}

As a conclusion, we have to consider and think about the essential and fundamental role that the Israeli Intelligence Community plays in safeguarding the country, in a computerized, globalized, turbulent and chaotic international system. Mossad, Aman and Shin Bet are fighting a war for the country's existence as a Nation, just the contrary of other Intelligence agencies. They are part of this war, and the fight against terrorism is essential because it is a lethal menace to the National Security. For this reason, the Israeli Intelligence Community will be asked to intervene in scenarios that are developing so much and so fast and to confront not only with the "classic" forms of terrorism but above all with new kinds of attacks against Israel.

In the future, Mossad, Aman and Shin Bet agents will be less operative in defeating the Israel enemies on the field and more involved in other kinds of spying and defence: it means fewer arms and more computers. The Mossad's efficiency myth (Desmaretz, 1999), that cracked in the 90's, is gradually gaining level and it is still shaped by men who had to defend themselves from everything and everyone, men who suffered from the Holocaust and turned up to the permanent war in Palestine since 1948.

The history of the Israeli Intelligence Community is certainly inseparable from Israel: they will always be where the National Security is concerned. Moreover, as Amit said to the students of Midraha-the academy where future agents are prepared and trained-as a conclusion to the training period: "No one is saying that is a funny job" (Colonna Vilasi, 2012).

\section{References}

Andrew, C. (2009). The Defence of the Realm. London: Allen Lane.

Colonna Vilasi, A. (2012). Gli scenari futuri del Mossad. Milano: Panorama.it. 
Colonna Vilasi, A. (2014). The History of Mossad. Bloomington, IN: Authorhouse-Penguin.

Desmaretz, G. (1999). Le grand livre de l'espionnage. Paris: Chiron.

Jeffery, K. (2010). MI6: The History of the Secret Intelligence Service 1909-1949. London, Bloomsbury.

Lituinoff, B.(2002). La lunga strada per Gerusalemme. Milano, Saggiatore.

Morris, B. (2000). 1948 and after. Israel and the Palestinians. Oxford: Clarendon Press.

Morris, B., \& Black, I. (2004). Mossad-Le guerre segrete di Israele. Milano, BUR.

Ostrovsky, V., \& Hoy, C. (1996). Attraverso l'inganno. Interno Giallo. Milano: Marco Tropea Editore.

Rodison, M. (1986). Israele e il rifiuto arabo. Milano: Feltrinelli. 